\title{
Leaky splicing variant in sepiapterin reductase deficiency
}

\author{
Are milder cases escaping diagnosis?
}

Yu Nakagama, MD,* Kohei Hamanaka, MD, PhD,* Masakazu Mimaki, MD, PhD, Haruo Shintaku, MD, PhD, Satoko Miyatake, MD, PhD, Naomichi Matsumoto, MD, PhD, Koji Hirohata, MD, Ryo Inuzuka, MD, PhD, and Akira Oka, MD, PhD

Neurol Genet 2019;5:e319. doi:10.1212/NXG.0000000000000319

Sepiapterin reductase deficiency (SRD), an extremely rare but treatable neurotransmitter disease, is an enzyme defect in the final step of tetrahydrobiopterin $\left(\mathrm{BH}_{4}\right)$ synthesis. ${ }^{1}$ Unlike other forms of $\mathrm{BH}_{4}$-deficient dopa-responsive dystonia, $\mathrm{SRD}$ uniquely does not manifest hyperphenylalaninemia and thus slips through detection by newborn screening. Owing to its variable presenting features and need for a sensitive method of CSF analysis, diagnosis of SRD may be compromised in mild phenotypes. ${ }^{2}$

We describe a novel splice site variant leading to leaky splicing control of the SPR gene. Our observation adds evidence to the notion that leaky splicing may take part in SRD heterogeneity and evokes the image of an iceberg beneath the water: patients at the milder end of the spectrum escaping recognition.

\section{Case report}

An 8-month-old girl presented with postural limb dystonia that worsened in the evening. Brain imaging, EEG, routine blood, urine, and CSF testing were nondiagnostic. Recognition of her episodic oculogyric crises and convergence spasms prompted us to analyze her CSF for pterins and biogenic amines. CSF homovanillic acid $(132 \mathrm{nmol} / \mathrm{L})$ and 5-hydroxyindoleacetic acid $(11.5 \mathrm{nmol} / \mathrm{L}$ ) were decreased (normal range: $295-932 \mathrm{nmol} / \mathrm{L}$ and $114-336 \mathrm{nmol} / \mathrm{L}$, respectively). The $\mathrm{CSF} \mathrm{BH}_{4}$ level, analyzed by the method described by Fukushima and Nixon, ${ }^{3}$ was below the detection limit, whereas total biopterin $(27.06 \mathrm{nmol} / \mathrm{L})$ and neopterin $(22.06$ $\mathrm{nmol} / \mathrm{L}$ ) levels were within the normal range, suggesting that most of the patient's total biopterin was a sum of biopterin and dihydrobiopterin. Findings were suggestive of monoamine neurotransmitter disease due to $\mathrm{BH}_{4}$ deficiency. L-dopa/carbidopa therapy completely suppressed her dystonia and resulted in near-normal psychomotor development.

Genetic analysis established the diagnosis of SRD by identifying compound heterozygous variants in the SPR gene (NM_003124.4): c.512G>A and c.304+1_+12del. The former is a novel missense variant, absent in the Exome Aggregation Consortium (ExAC) and gnomAD databases, estimated to substitute a well-conserved cysteine for tyrosine, and predicted as damaging according to in silico analyses. The latter, also absent in the ExAC and gnomAD databases, destroys the $5^{\prime}$ splice donor site in intron 1 , rendering the gene prone to aberrant splicing (figure, A).

\author{
Correspondence \\ Dr. Nakagama \\ ynakagama-tky@umin.ac.jp
}

\footnotetext{
*These authors contributed equally to this work.

From the Department of Pediatrics (Y.N., K. Hirohata, R.I., A.O.), Graduate School of Medicine, The University of Tokyo; Department of Human Genetics (K. Hamanaka, S.M., N.M.), Graduate School of Medicine, Yokohama City University; Department of Pediatrics (M.M.), School of Medicine, Teikyo University, Tokyo; and Department of Pediatrics (H.S.), Graduate School of Medicine, Osaka City University, Osaka, Japan.

Funding information and disclosures are provided at the end of the article. Full disclosure form information provided by the authors is available with the full text of this article at Neurology.org/NG.

The Article Processing Charge was funded by the authors.

Patient consent: Written consent for publication was obtained from the patient's family.

This is an open access article distributed under the terms of the Creative Commons Attribution-NonCommercial-NoDerivatives License 4.0 (CC BY-NC-ND), which permits downloading and sharing the work provided it is properly cited. The work cannot be changed in any way or used commercially without permission from the journal.
} 
Figure Mutational and splicing analyses

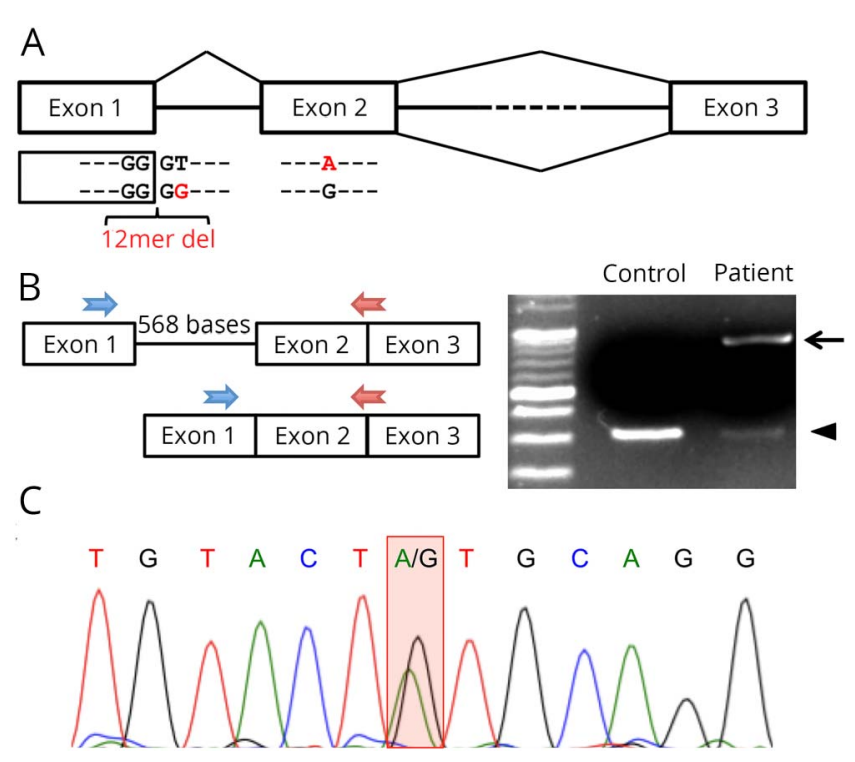

(A) The patient was compound heterozygous for an exonic C.512G>A and an intronic c.304+1 +12del (SPR, NM 003124.4) (B and C) The destroyed splice site and retention of intron 1 resulted in a larger size 899-bp band (B, arrow) specific to the patient. Because allelic origin was identifiable based on the c.512G $>$ A variant, sequencing the normally spliced 319-bp product ( $B$, arrowhead) showed significant wild-type splicing from the allele carrying c.304+1_+12del (C). Primers were designed as depicted, and sequences are available upon request.

Next, splicing analysis was performed, using blood cell transcripts extracted from the patient and a healthy control. Primers were designed to flank intron 1 and exon 2 of the SPR gene and to specifically amplify the RNA sequences (figure B). Reverse transcription-PCR-based splicing analysis not only confirmed aberrant splicing causing intron retention (figure B, arrow) but also discovered evidence for leaky splicing control related to c.304+1_+12del. Because the allelic origin was identifiable based on the presence or absence of c.512G $>$ A, directly sequencing the shorter 319-bp amplicon (figure $B$, arrowhead) showed significant wild-type splicing from the allele carrying c.304+1_+12del (figure C).

\section{Discussion}

Leaky splicing control contributes to phenotypic variation by affecting disease onset and/or severity. The extent of leaky wild-type transcription determines, for example, residual acid alpha-glucosidase activity in Pompe disease and relates to a specific-form of adult-onset disease. ${ }^{4}$ As for SRD, others have reported the possibility of leaky splicing causing intrafamilial heterogeneity. ${ }^{5}$ In the report, however, splicing was assessed indirectly using the minigene system. Our report proves by directly analyzing patient RNA that leaky splice site variants indeed underlie SRD. Phenotypic variability owing to such leaky splicing control may further expand the SRD spectrum.

\section{Study funding}

Supported by grants from Morinaga Hoshikai and AMED (JP18ek0109280 and JP18ek0109301).

\section{Disclosure}

Y. Nakagama has received government research support from JSPS Kakenhi and has received foundation/society research support from Morinaga Hoshikai. K. Hamanaka and M. Mimaki report no disclosures. H. Shintaku has received government research support from the AMED. S. Miyatake has received foundation/society research support from the Kawano Masanori Memorial Public Interest Incorporated Foundation for Promotion of Pediatrics, JSPS KAKENHI, and The Ichiro Kanehara Foundation for the Promotion of Medical Science \& Medical Care. N. Matsumoto has served on the editorial boards of Clinical Genetics, Journal of Human Genetics, and American Journal of Medical Genetics and has received foundation/society research support from the AMED, JSPS KAKENHI, and Takeda Science Foundation. K. Hirohata reports no disclosures. R. Inuzuka has served on the editorial board of Journal of Pediatric Cardiology and Cardiac Surgery and has received government research support from JSPS KAKENHI. A. Oka has received funding for travel or speaker honoraria from Otsuka Pharmaceutical, UCB Japan, Nobelpharma, Janssen Pharmaceutical, Eisai, BioMarin Pharmaceutical, Novartis Pharma K.K., GE Healthcare Japan, Teijin Pharma Limited, Shionogi \& Co., Shire Japan, Bayer Yakuhin, and SRL Inc.; has served on the editorial board of Pediatrics International; has commercial research support from Maruho Co, Pfizer Japan, Astellas Pharma, Novartis Pharma K.K., Chugai Pharmaceutical Co., and Eli Lilly Japan K.K.; and has received government funding from The Ministry of Health Labour and Welfare Japan. Disclosures available: Neurology.org/NG.

\section{Publication history}

Received by Neurology: Genetics October 26, 2018. Accepted in final form February 8, 2019.

Appendix Author contributions

\begin{tabular}{llll}
\hline Name & Location & Role & Contribution \\
\hline $\begin{array}{l}\text { Yu } \\
\text { Nakagama, } \\
\text { MD }\end{array}$ & $\begin{array}{l}\text { The University } \\
\text { of Tokyo, } \\
\text { Tokyo }\end{array}$ & Author & $\begin{array}{l}\text { Interpreted clinical data, } \\
\text { performed splicing analysis, } \\
\text { and drafted the manuscript. }\end{array}$ \\
$\begin{array}{l}\text { Masakazu } \\
\begin{array}{l}\text { Mimaki, MD, } \\
\text { PhD }\end{array}\end{array}$ & $\begin{array}{l}\text { Teikyo } \\
\text { University, }\end{array}$ & Author & $\begin{array}{l}\text { Interpreted clinical data and } \\
\text { revised the manuscript. }\end{array}$ \\
$\begin{array}{l}\text { Haruo } \\
\text { Shintaku, } \\
\text { MD, PhD }\end{array}$ & $\begin{array}{l}\text { Osaka City } \\
\text { Oniversity, }\end{array}$ & Author & $\begin{array}{l}\text { Performed CSF analysis for } \\
\text { Osterins and amines. }\end{array}$ \\
\hline $\begin{array}{l}\text { Kohei } \\
\text { Hamanaka, } \\
\text { MD, PhD }\end{array}$ & $\begin{array}{l}\text { Yokohama City } \\
\text { Yniversity, }\end{array}$ & Author & $\begin{array}{l}\text { Performed genetic analysis } \\
\text { Yokohama interpreted results. }\end{array}$ \\
\hline
\end{tabular}




\begin{tabular}{|c|c|c|c|}
\hline Name & Location & Role & Contribution \\
\hline $\begin{array}{l}\text { Satoko } \\
\text { Miyatake, } \\
\text { MD, PhD }\end{array}$ & $\begin{array}{l}\text { Yokohama City } \\
\text { University, } \\
\text { Yokohama }\end{array}$ & Author & $\begin{array}{l}\text { Performed genetic analysis } \\
\text { and interpreted results. }\end{array}$ \\
\hline $\begin{array}{l}\text { Naomichi } \\
\text { Matsumoto, } \\
\text { MD, PhD }\end{array}$ & $\begin{array}{l}\text { Yokohama City } \\
\text { University, } \\
\text { Yokohama }\end{array}$ & Author & $\begin{array}{l}\text { Performed genetic analysis } \\
\text { and interpreted results. }\end{array}$ \\
\hline $\begin{array}{l}\text { Koji } \\
\text { Hirohata, } \\
\text { MD }\end{array}$ & $\begin{array}{l}\text { The University } \\
\text { of Tokyo, } \\
\text { Tokyo }\end{array}$ & Author & $\begin{array}{l}\text { Interpreted clinical data and } \\
\text { revised the manuscript. }\end{array}$ \\
\hline $\begin{array}{l}\text { Ryo Inuzuka, } \\
\text { MD, PhD }\end{array}$ & $\begin{array}{l}\text { The University } \\
\text { of Tokyo, } \\
\text { Tokyo }\end{array}$ & Author & $\begin{array}{l}\text { Critically revised the } \\
\text { manuscript. }\end{array}$ \\
\hline $\begin{array}{l}\text { Akira Oka, } \\
\text { MD, PhD }\end{array}$ & $\begin{array}{l}\text { The University } \\
\text { of Tokyo, } \\
\text { Tokyo }\end{array}$ & Author & $\begin{array}{l}\text { Critically revised the } \\
\text { manuscript. }\end{array}$ \\
\hline
\end{tabular}

\section{References}

1. Bonafé L, Thöny B, Penzien JM, Czarnecki B, Blau N. Mutations in the sepiapterin reductase gene cause a novel tetrahydrobiopterin-dependent monoamineneurotransmitter deficiency without hyperphenylalaninemia. Am J Hum Genet 2001;69:269-277.

2. Ng J, Papandreou A, Heales SJ, Kurian MA. Monoamine neurotransmitter disordersclinical advances and future perspectives. Nat Rev Neurol 2015;11:567-584.

3. Fukushima T, Nixon JC. Analysis of reduced forms of biopterin in biological tissues and fluids. Anal Biochem 1980;102:176-188.

4. Boerkoel CF, Exelbert R, Nicastri C, et al. Leaky splicing mutation in the acid maltase gene is associated with delayed onset of glycogenosis type II. Am J Hum Genet 1995; 56:887-897.

5. Arrabal L, Teresa L, Sánchez-Alcudia R, et al. Genotype-phenotype correlations in sepiapterin reductase deficiency. A splicing defect accounts for a new phenotypic variant. Neurogenetics 2011;12:183-191. 


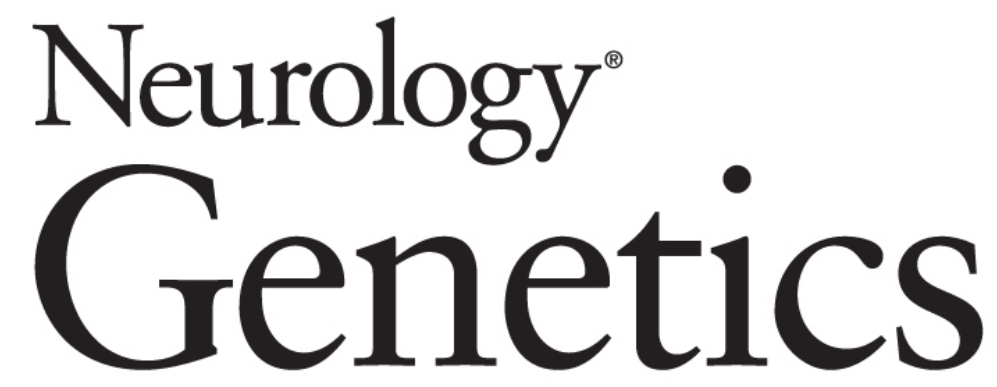

Leaky splicing variant in sepiapterin reductase deficiency: Are milder cases escaping diagnosis?

Yu Nakagama, Kohei Hamanaka, Masakazu Mimaki, et al. Neurol Genet 2019;5;

DOI 10.1212/NXG.0000000000000319

This information is current as of March 25, 2019

Neurol Genet is an official journal of the American Academy of Neurology. Published since April 2015, it is an open-access, online-only, continuous publication journal. Copyright Copyright ( 2019 The Author(s). Published by Wolters Kluwer Health, Inc. on behalf of the American Academy of Neurology.. All rights reserved. Online ISSN: 2376-7839.

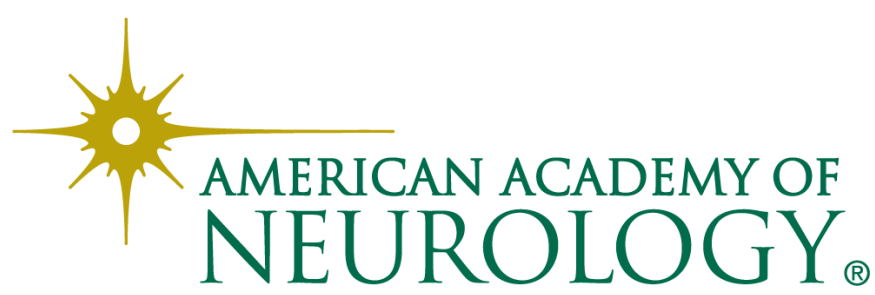




\section{Updated Information \& Services}

References

Subspecialty Collections

Permissions \& Licensing

\section{Reprints}

including high resolution figures, can be found at: http://ng.neurology.org/content/5/2/e319.full.html

This article cites 5 articles, 0 of which you can access for free at: http://ng.neurology.org/content/5/2/e319.full.html\#\#ref-list-1

This article, along with others on similar topics, appears in the following collection(s):

\section{All Genetics}

http://ng.neurology.org//cgi/collection/all_genetics

All Pediatric

http://ng.neurology.org//cgi/collection/all_pediatric

Dystonia

http://ng.neurology.org//cgi/collection/dystonia

Gene expression studies

http://ng.neurology.org//cgi/collection/gene_expression_studies

Metabolic disease (inherited)

http://ng.neurology.org//cgi/collection/metabolic_disease_inherited

Information about reproducing this article in parts (figures,tables) or in its entirety can be found online at:

http://ng.neurology.org/misc/about.xhtml\#permissions

Information about ordering reprints can be found online:

http://ng.neurology.org/misc/addir.xhtml\#reprintsus

Neurol Genet is an official journal of the American Academy of Neurology. Published since April 2015, it is an open-access, online-only, continuous publication journal. Copyright Copyright ( 2019 The Author(s). Published by Wolters Kluwer Health, Inc. on behalf of the American Academy of Neurology.. All rights reserved. Online ISSN: 2376-7839.

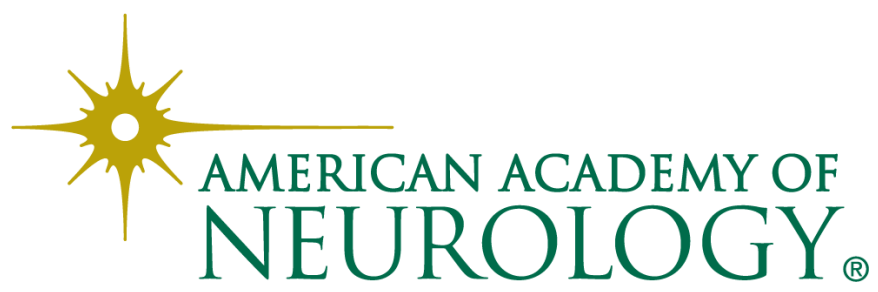

